\title{
Prolonged estuarine habitat use by dusky grouper Epinephelus marginatus at subtropical latitudes revealed by otolith microchemistry
}

\author{
M. V. Condini' ${ }^{1, *}$, S. E. Tanner ${ }^{2}$, P. Reis-Santos ${ }^{2,3}$, C. Q. Albuquerque ${ }^{4}$, \\ T. D. Saint'Pierre ${ }^{5}$, J. P. Vieira ${ }^{1}$, H. N. Cabral ${ }^{2}$, A. M. Garcia ${ }^{1}$ \\ ${ }^{1}$ Laboratório de Ictiologia, Instituto de Oceanografia, Universidade Federal de Rio Grande, Av. Itália Km 08, Carreiros, \\ CEP: 96.201-900, Rio Grande, RS, Brazil \\ ${ }^{2}$ MARE - Marine and Environmental Sciences Centre, Faculdade de Ciências, Universidade de Lisboa, \\ 1749-016 Campo Grande, Lisboa, Portugal \\ ${ }^{3}$ Southern Seas Ecology Laboratories, School of Biological Sciences, The University of Adelaide, SA 5005, Australia \\ ${ }^{4}$ Departamento de Ciências Animais, Universidade Federal Rural do Semi-Árido, CEP: 59625-900, Mossoró, RN, Brazil \\ ${ }^{5}$ Departamento de Química, Pontifícia Universidade Católica do Rio de Janeiro, Rua Marquês de São Vicente, 225,
} Gávea, 22451-900, Rio de Janeiro, Brazil

\begin{abstract}
Otolith microchemistry ( $\mathrm{Sr}: \mathrm{Ca}, \mathrm{Ba}: \mathrm{Ca})$ was used to evaluate habitat use patterns of the endangered dusky grouper Epinephelus marginatus in southern Brazil. Individual Sr:Ca profiles exhibited low variation, with an overall tendency to increase with age. Interestingly, individual Ba:Ca profiles presented 3 contrasting patterns: the first comprised most sampled individuals $(>80 \%)$, mostly indicative of the predominant use of marine waters throughout their life history; the second pattern ( $10 \%$ of all individuals) indicated that dusky grouper may use or remain in or near estuarine waters for short time periods; finally, the third identified pattern $(\sim 5 \%)$ comprised individuals remaining in estuarine waters for long periods and provided the first evidence for this species of prolonged estuarine habitat use (over a year), in particular during juvenile life stages.
\end{abstract}

KEY WORDS: Epinephelidae - Fish conservation ' Life-history plasticity - Movement · Natural tags $\cdot$ Patos Lagoon

\section{INTRODUCTION}

Dusky grouper Epinephelus marginatus (Lowe, 1834 ) is the only large Epinephelidae species commonly found along subtropical latitudes (above $30^{\circ} \mathrm{S}$ ) of the southwestern Atlantic Ocean, where it inhabits shelter-rich hard substrata on the continental shelf (Heemstra \& Randall 1993, Sluka et al. 2001, Reñones et al. 2002). This species is highly prized by commercial fisheries and represents a significant source of income to fishermen (Condini et al. 2007, Craig et al. 2011, Sadovy de Mitcheson et al. 2013). Overfishing combined with a complex life-

\footnotetext{
*Corresponding author: mvcondini@gmail.com
}

history strategy (slow growth rate, late maturation, aggregative spawning behavior and sequential hermaphroditism, a trait common to several grouper species [Heemstra \& Randall 1993, Craig et al. 2011]) has led to the high vulnerability of many grouper populations (Graham et al. 2009, Cheung et al. 2013, Sadovy de Mitcheson et al. 2013), and in particular to the classification of E. marginatus as 'Endangered' (EN a2d) in the IUCN Red List (Cornish \& Harmelin-Vivien 2004).

Recent studies on E. marginatus in southern Brazil comparing littoral and neritic sites have suggested that Carpinteiro Bank (a neritic site) is the main

() The authors 2016. Open Access under Creative Commons by Attribution Licence. Use, distribution and reproduction are unrestricted. Authors and original publication must be credited. 
growth and spawning ground for this species in the region (Condini et al. 2014a,b). In contrast, only immature individuals and resting mature females are found along rocky substrate in the littoral zone (Seyboth et al. 2011). Although comparative studies suggest that dusky grouper growth rates are higher in neritic habitats (Condini et al. 2014b), the relative importance of the different habitats for this endangered species remains unknown. A better understanding of habitat use patterns of marine fish populations is vital to evaluate their dynamics and resilience to harvest, ultimately supporting adequate management and conservation measures (Andrello et al. 2014, Davoren et al. 2015). This fundamental aspect of fish life history can be revealed through the evaluation of natural markers such as otolith microchemistry (Rooker et al. 2008, Reis-Santos et al. 2013a, Darnaude et al. 2014), as detailed analysis of the chemical composition of otoliths allows reconstruction of the environmental conditions experienced by individual fish throughout their entire life history (Campana 1999, Elsdon et al. 2008, Tanner et al. 2013). In general, strontium ( $\mathrm{Sr}$ ) and barium (Ba) concentrations in otoliths have a positive correlation with salinity and freshwater, respectively (Elsdon \& Gillanders 2005, Sturrock et al. 2012, Reis-Santos et al. 2013b). Thus, fish living in marine waters present higher otolith strontium concentrations compared to fish living in freshwater, whereas the latter present conspicuously higher otolith Ba concentrations than fish living in marine waters.
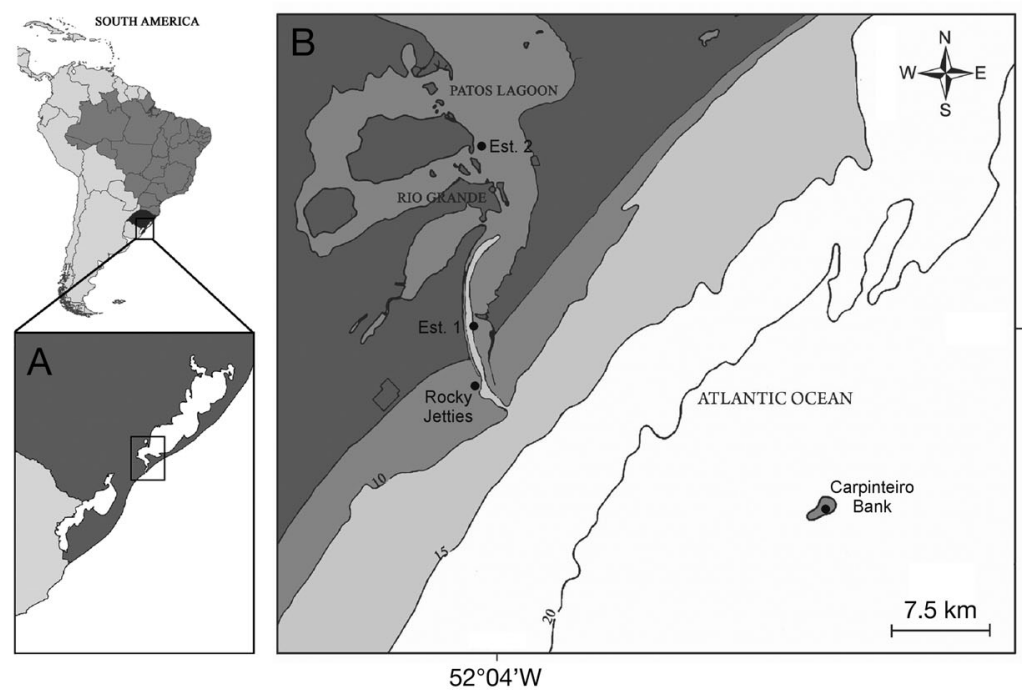

Fig. 1. Patos Lagoon $\left(10360 \mathrm{~km}^{2}\right)$ and its estuarine zone in the state of Rio Grande do Sul, southern Brazil (A), showing the locations of the 2 sampling sites (rocky jetties and Carpinteiro Bank), as well as 2 sites related to salinity data (Est. 1 and Est. 2) (B). Lines along the coast denote 10 (dark gray), 15 (light gray) and $20 \mathrm{~m}$ (white) isobaths, respectively
The aim of this study was to investigate habitat use patterns of dusky grouper E. marginatus in subtropical latitudes $\left(32^{\circ} \mathrm{S}\right)$ in the southwestern Atlantic Ocean. Findings may provide key insights on habitat use of different life-history stages which could be useful in the design of Marine Protected Areas and help to ensure the conservation of this endangered species at the southern limit of its distribution.

\section{MATERIALS AND METHODS}

Sampling was conducted at 2 locations on the southern Brazilian coast (Fig. 1). The first one is located in the littoral zone (rocky jetties, $<5 \mathrm{~m}$ in depth), at the mouth of the Patos Lagoon estuary $\left(\sim 1000 \mathrm{~km}^{2}\right)$, and is constituted of a pair of $4.5 \mathrm{~km}$ long rocky jetties (Fig. $1 ; 32^{\circ} 09^{\prime} \mathrm{S}, 52^{\circ} 05^{\prime} \mathrm{W}$ ). Due to its position, this sampling location has varying hydrological conditions and freshwater inputs that affect its salinity profiles (Moller et al. 2001). The second sampling site is the Carpinteiro Bank (Fig. $1 ; 32^{\circ} 16^{\prime} \mathrm{S}$, $51^{\circ} 47^{\prime} \mathrm{W}$ ), a group of submerged rocks 20 to $30 \mathrm{~m}$ deep in the neritic zone approximately 16 nautical miles $(\sim 30 \mathrm{~km})$ from the coast.

Dusky grouper Epinephelus marginatus were collected from the littoral and neritic zones in collaboration with regional fishermen. Otoliths of a total of 72 individuals of E. marginatus were extracted for chemical analysis; 28 of these individuals, aged between 2 and $12 \mathrm{yr}$ (mean $\pm \mathrm{SD}: 4.8 \pm 2.4 \mathrm{yr}$ ), were sampled in the littoral zone (rocky jetties) and 44, aged between 2 and $40 \mathrm{yr}(11.9 \pm 10.8 \mathrm{yr})$, were sampled in the neritic zone (Carpinteiro Bank). Age determination using otoliths has already been validated for E. marginatus in this study area (Condini et al. 2014b). All procedures for otolith chemical analysis followed Mai et al. (2014). Each otolith section was scanned from the core to the edge using a $266 \mathrm{~nm}$ laser ablation system (CETAC LSX 100) coupled to an ELAN 6000 (PerkinElmer-SCIEX) inductively coupled plasma-mass spectrometer (ICP-MS), and calcium $\left({ }^{43} \mathrm{Ca}\right),{ }^{86} \mathrm{Sr}$ and ${ }^{138} \mathrm{Ba}$ were measured. Blank ablations (background intensities) were measured during $50 \mathrm{~s}$ after every 10 otolith ablations. Strontium and calcium counts per second (cps) were subtracted from the background 
Fig. 2. Ba:Ca ratio profiles along a transect from the core to the posterior edge of the otolith of Epinephelus marginatus collected from the littoral (RJ) and neritic (CB) zone, with age (yr) and total length (TL, $\mathrm{mm}$ ) of each analyzed individual. All element:Ca ratios correspond to counts per second. Arrows indicate the end of the juvenile stage; before the arrow individuals are $<5 \mathrm{yr}$ old. The black line denotes a 3 -order moving average, which was employed for better visualization of the elemental chemical profile trend exhibited by each individual otolith

level, and element:Ca ratios were then calculated for all otoliths. Before analyzing otoliths, the instrument was optimized through daily performance, with maximum analyte intensities and minimum interferences determined using oxides and double-charged ions. Repeatability was estimated as the relative standard deviation (RSD) from 10 consecutive measurements of the standard NIST 1834, resulting in relative standard deviations of $12.43,6.91$ and $3.99 \%$ for ${ }^{138} \mathrm{Ba}$, ${ }^{86} \mathrm{Sr}$ and ${ }^{43} \mathrm{Ca}$, respectively.

As the Carpinteiro Bank (a neritic zone) has been identified as an important spawning site for E. marginatus in southern Brazil (Condini et al. 2014a) and taking into consideration the close location of the littoral habitat (16 nautical miles), all individuals used in this study were assumed to belong to the same population; this assumption is corroborated by the long distances that dusky grouper larvae can disperse ( $>16$ nautical miles; Andrello et al. 2014). To reconstruct and characterize habitat use patterns of E. marginatus, we analyzed the $\mathrm{Sr}: \mathrm{Ca}$ and Ba:Ca lifehistory profiles of all $72 \mathrm{E}$. marginatus individuals collected from both littoral and neritic areas. In addition, otolith edge $\mathrm{Sr}: \mathrm{Ca}$ and $\mathrm{Ba}: \mathrm{Ca}$ ratios of individuals collected at littoral and neritic sites were compared using non-parametric Mann-Whitney $U$-tests to evaluate our ability to distinguish between sampled areas. For this comparison only fish from matching year classes (aged between 6 and 8 yr old and
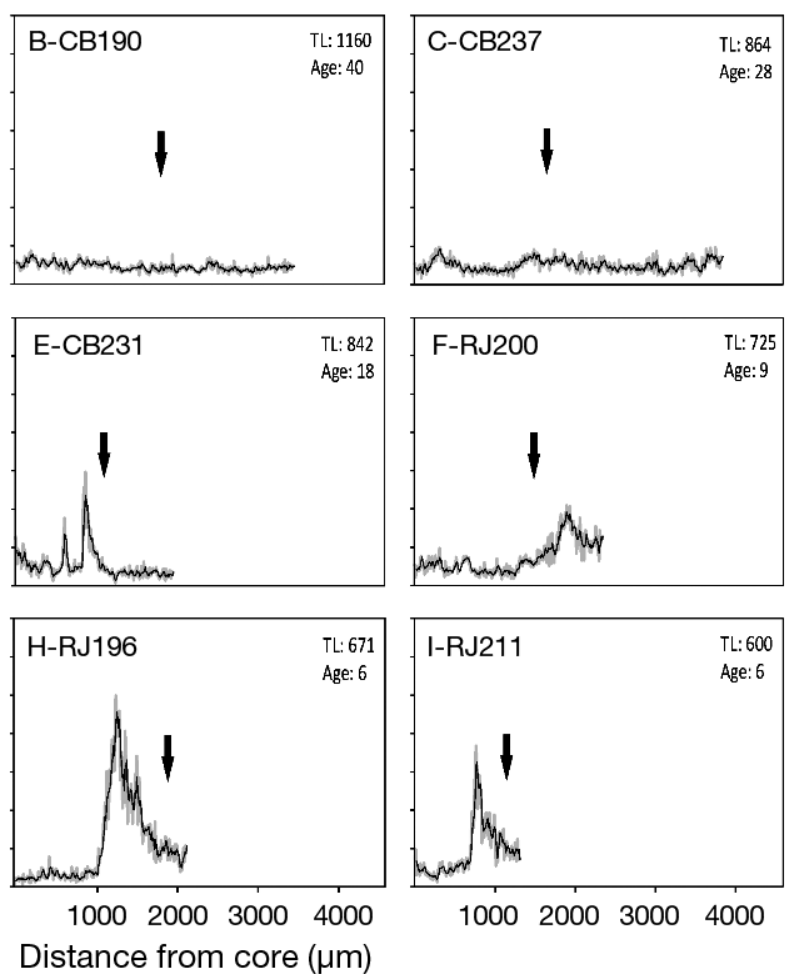

born between 2000 and 2003) were used to avoid any potential influence of ontogenetic and temporal variations: specifically, 12 individuals from littoral (587.6 $\pm 44.9 \mathrm{~mm}$ TL) and 8 from neritic zones (619.0 \pm $36.1 \mathrm{~mm}$ TL). Otolith edge chemical composition was defined as the $30 \mu \mathrm{m}$ nearest to the edge of the otolith.

Salinity data over time were analyzed from a $40 \mathrm{yr}$ time series for the Carpinteiro Bank region (specifically, from 32 to $32^{\circ} 50^{\prime} \mathrm{S}$ and 50 to $52^{\circ} \mathrm{W}$ ) and a $20 \mathrm{yr}$ time series for littoral and estuarine areas. Data were obtained from the Coastal and Estuarine Oceanography Laboratory of Rio Grande Federal University and the Ichthyology Laboratory of Rio Grande Federal University, respectively. Salinity data were averaged by month and reported with respective standard deviations.

\section{RESULTS AND DISCUSSION}

We found 3 interesting patterns of Ba:Ca life-time profiles in Epinephelus marginatus that indicate differential habitat use. The first comprises most sampled individuals $(>80 \%)$ and is characterized by low $\mathrm{Ba}$ :Ca ratios $(<0.03)$ along an individual's entire life history (Fig. 2A-C; Fig. S1 in the Supplement at www.int-res.com/articles/suppl/n029p271_supp.pdf) and is mostly indicative of the predominant use of marine waters throughout their life history. The sec- 

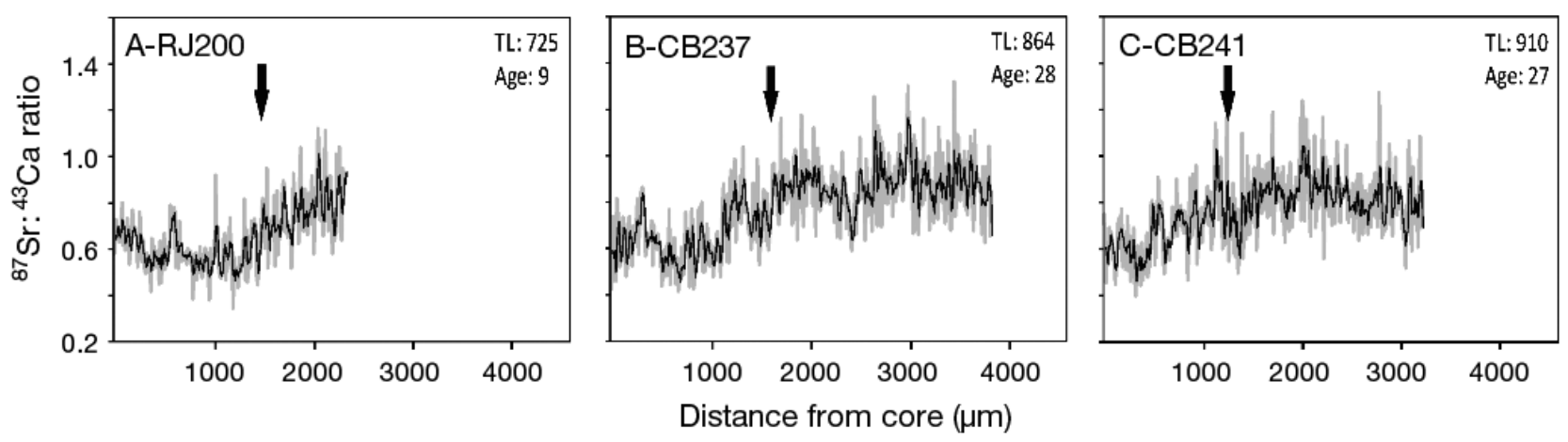

Fig. 3. Sr:Ca ratio profiles along a transect from the core to the posterior edge of the otolith of Epinephelus marginatus collected from the littoral (RJ) and neritic (CB) zone, with age (yr) and total length (TL, mm) of each analyzed individual. All element:Ca ratios correspond to counts per second. Arrows indicate the end of the juvenile stage; before the arrow individuals are $<5$ yr old. The black line denotes a 3-order moving average, which was employed for better visualization of the elemental chemical profile trend exhibited by each individual otolith

ond pattern includes juveniles and adults $(\sim 10 \%$ of all individuals) that exhibited small fluctuations in otolith Ba:Ca ratios, with peaks reaching values between 0.03 and 0.05 (Fig. 2D-F); this indicates that these fish may use or remain in, or near, estuarine waters for short time periods. Finally, the third identified pattern $(\sim 5 \%)$ comprises individuals with a steep increase in Ba:Ca ratios (up to a maximum of 0.14; Fig. 2G-I) during their juvenile stage, followed by a decrease to early life levels $(<0.03)$. This pattern appeared mostly, though not exclusively, in fish sampled in the littoral habitat and suggests these fish remained within the Patos Lagoon estuary for extended periods of time (over $2 \mathrm{yr}$ in some cases).

Our findings support the conclusions that dusky groupers have higher life-history plasticity than previously reported and that estuaries may be used as alternative habitats by some individuals during part of their lives. To our knowledge, there is no prior evidence in the literature of E. marginatus inhabiting brackish waters for such extended periods, though this is not entirely surprising, as juveniles of the Epinephelus genus (e.g. E. striatus, E. coiodes, E. malabaricus, E. aeneus, E. itajara) are known to use mangroves, coastal lagoons and estuaries as nursery or juvenile habitats (Heemstra \& Randall 1993, Craig et al. 2011). Yet, until now, there have been only a few scattered records of occurrence of E. marginatus near, or within, estuarine areas (e.g. Barbanti et al. 2013, M. V. Condini unpubl. data), and no prior information on consistent use of estuaries or permanence in brackish waters.

Other studies using otolith chemistry of different species inhabiting the Patos Lagoon estuary and adjacent coastal areas (e.g. Genidens genidens and Mugil liza) showed similar ranges of otolith $\mathrm{Ba}$ :Ca when mi- grating along the salinity gradient of this estuarine system. For instance, otoliths of G. genidens showed average Ba:Ca ratios of approximately 0.08 in the estuary, which increased to $\sim 0.13$ in the freshwater portion of the Patos Lagoon (Pereyra 2015). Ba:Ca values ranging from 0.01 to 0.14 were also reported for Lycengraulis grossidens and Genidens barbus collected along the Patos Lagoon salinity gradient (Mai et al. 2014, Avigliano et al. 2015). We recognize that inter-specific variations in otolith microchemistry may sometimes preclude comparisons between different species (Reis-Santos et al. 2008). However, as we show here, many migrant fish species presented similar ranges of $\mathrm{Ba}: \mathrm{Ca}$ ratios in their otoliths along the Patos Lagoon estuary. Also, most studies indicate that water is the major source of otolith elements and that diet has little or no effect on otolith elemental composition (Walther \& Thorrold 2006, Gibson-Reinemer et al. 2009, Marohn et al. 2009), which helps to discard potential confounding effects of diet in our results. In contrast to $\mathrm{Ba}: \mathrm{Ca}$, individual $\mathrm{Sr}: \mathrm{Ca}$ profiles exhibited low variation, with an overall tendency to increase with age, regardless of which site individuals were collected from (Fig. 3; Fig. S2 in the Supplement at www.int-res.com/articles/suppl/n029p271_supp.pdf). Albuquerque et al. (2012) observed little or no variation in $\mathrm{Sr}$ :Ca ratios in the water between intermediate ( 20) and high ( 35) salinities along the freshwatermarine gradient in the estuarine system of Patos Lagoon. Similar results have also been observed by Phillis et al. (2011) in San Francisco Bay related to the $\mathrm{Ca}$ concentration of the freshwater end-member. However, higher than expected Sr or Ca end-member availability in the ambient water of the Patos Lagoon cannot be excluded, due to lack of available information (see Kraus \& Secor 2004). 


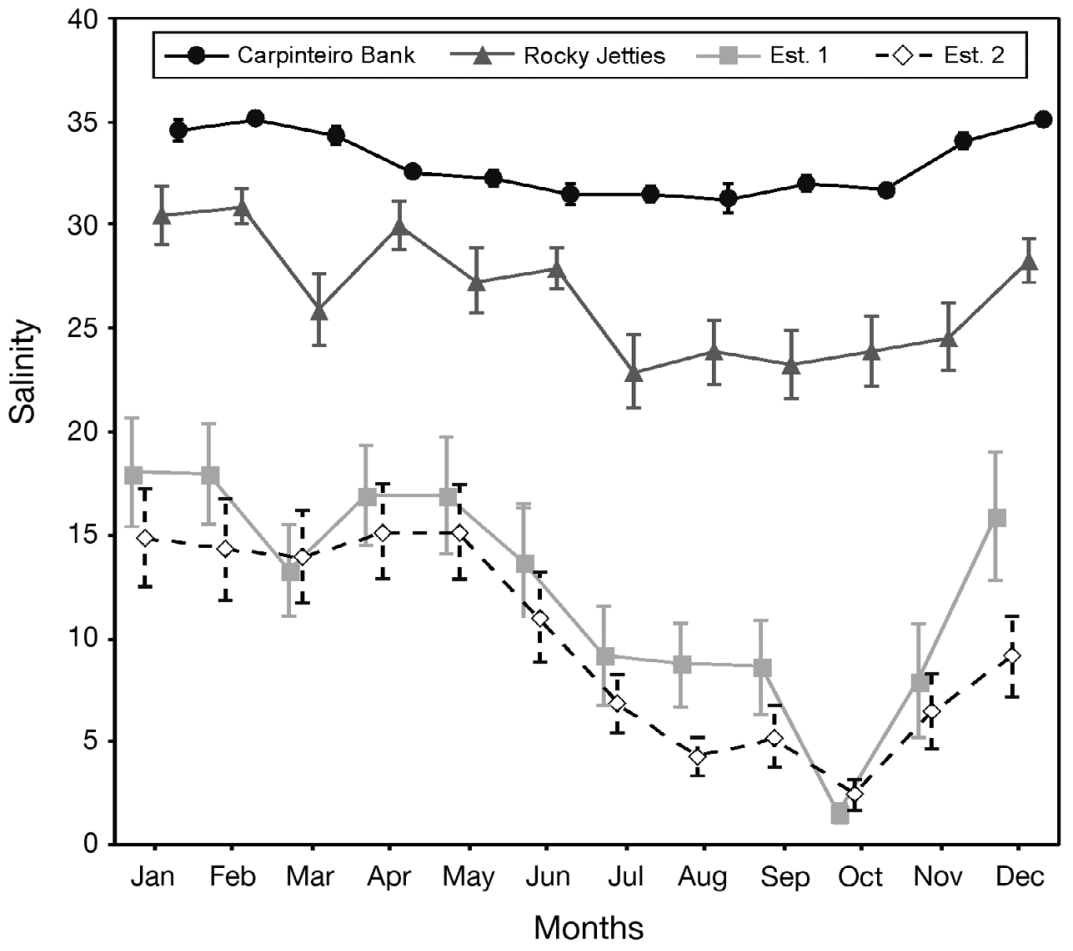

Fig. 4. Mean values $( \pm \mathrm{SE})$ of salinity in Patos Lagoon estuary (Est. 1 and Est. 2) and at both marine sampling sites, the littoral (rocky jetties) and neritic zone (Carpinteiro Bank)

Climatic interannual variability is considerable in the study region. For instance, the strong El Niño Southern Oscillation (ENSO) event that occurred in 2002 (birth year of some of the individuals analyzed here), led to positive rainfall anomalies in this region that increased freshwater discharge into the lagoon, which, in turn, had significant effects on fish distribution and abundance (Garcia et al. 2003, 2004). However, no generalized substantial increases in $\mathrm{Ba}: \mathrm{Ca}$ ratios in E. marginatus otoliths were observed, nor was it possible to link these to the increased freshwater runoff produced by this or other similar climatic events. Thus, the abrupt increase in the $\mathrm{Ba}: \mathrm{Ca}$ ratio in some of the analyzed individuals (Fig. 2G-I) was not related to the ENSO phenomenon, but indicative of juvenile entrance and residency for periods of at least $2 \mathrm{yr}$ in brackish estuarine waters.

Otolith edge $\mathrm{Sr}: \mathrm{Ca}$ and $\mathrm{Ba}: \mathrm{Ca}$ ratios from individuals collected in littoral and neritic habitats were compared to determine the discriminatory power of otolith chemical signatures. The influence of the estuarine plume of the Patos Lagoon causes average salinity at the littoral site (mean $=26.5$ ) to be lower than that at the neritic site (mean $=32.9$ ), as well as more variable year-round ( $\mathrm{SD}=7.0$ and 2.1 in littoral and neritic zones, respectively) (Fig. 4). Although there is a known positive correlation of $\mathrm{Sr}: \mathrm{Ca}$ with salinity and Ba:Ca with freshwater (Elsdon \& Gillanders 2005, Sturrock et al. 2012, Reis-Santos et al. 2013b), the mean concentrations of both element:Ca ratios in the otolith edge were not significantly different between individuals of the same year class caught in the neritic and littoral zones (Mann-Whitney $U=290$ and p > 0.05 for $\mathrm{Sr}: \mathrm{Ca}$; $U=268, \mathrm{p}>0.05$ for $\mathrm{Ba}: \mathrm{Ca})$. We hypothesize that the salinity difference, as well as the freshwater input, was not large enough in this case to produce distinct otolith chemical signatures between the 2 sampled habitats, hindering our ability to use otolith chemistry to disentangle movements between these 2 proximate coastal marine areas (as pointed out by Albuquerque et al. 2012 for $\mathrm{Sr}: \mathrm{Ca}$ and salinity ranges of these areas).

In conclusion, the present study revealed for the first time that individuals of E. marginatus can remain for prolonged time periods in a brackish system, highlighting the life-cycle plasticity of this endangered species. Future studies should actively investigate the occurrence of dusky groupers within estuarine systems, focusing on identifying key juvenile habitats for this species via combinations of other natural tags (e.g. stable isotopes of $\mathrm{C}$ and $\mathrm{O}$ ) and/or telemetry, which may also aid in resolving movements between littoral and neritic habitats of adult fish. Finally, it would also be of great interest to ascertain the physiological trade-offs related to the observed differential nursery habitat use. Overall, rocky jetties and estuarine habitats within the Patos Lagoon may be considered as potential candidates for the implementation of conservation strategies to safeguard this endangered species.

Acknowledgements. We thank the anonymous reviewers for their contribution towards improving this manuscript. This study received financial support from the CAPES-Brasil (PVE No. A101/2013) and Fundação O Boticário de Proteção a Natureza (0962_20122). M.V.C. and A.M.G. acknowledge fellowship support from the Conselho Nacional de Desenvolvimento Científico e Tecnológico (CNPq: 140570/2013-6 and 305888/2012-9, respectively). This study also received support from the Fundação para a Ciência e a Tecnologia (FCT) (UID/MAR/04292/2013 and PTDC/MAR/117084/ 2010). S.E.T. and P.R.S. were funded by FCT postdoctoral grants (SFRH/BPD/84278/2012 and SFRH/BPD/95784/2013, respectively). 


\section{LITERATURE CITED}

Albuquerque CQ, Miekeley N, Muelbert JH, Walther BD, Jaureguizar AJ (2012) Estuarine dependency in a marine fish evaluated with otolith chemistry. Mar Biol 159: 2229-2239

Andrello M, Mouillot D, Beuvier J, Albouy C, Thuiller W, Manel S (2013) Low connectivity between Mediterranean Marine Protected Areas: a biophysical modeling approach for the dusky grouper Epinephelus marginatus. PLoS ONE 8:e68564

> Avigliano E, Velasco G, Volpedo AV (2015) Assessing the use of two southwestern Atlantic estuaries by different life cycle stages of the anadromous catfish Genidens barbus (Lacépède, 1803) as revealed by $\mathrm{Sr}: \mathrm{Ca}$ and $\mathrm{Ba}: \mathrm{Ca}$ ratios in otoliths. J Appl Ichthyol 31:740-743

Barbanti B, Caires R, Marceniuk AP (2013) The ichthyofauna of the Bertioga Channel, São Paulo, Brazil. Biota Neotrop 13:276-291

> Campana SE (1999) Chemistry and composition of fish otoliths: pathways, mechanisms and applications. Mar Ecol Prog Ser 188:263-297

> Cheung WWL, Sadovy de Mitcheson Y, Braynen MT, Gittens LG (2013) Are the last remaining Nassau grouper Epinephelus striatus fisheries sustainable? Status quo in the Bahamas. Endang Species Res 20:27-39

Condini MV, Garcia AM, Vieira JP (2007) Descrição da pesca e perfil sócio-econômico do pescador da garoupaverdadeira Epinephelus marginatus (Lowe) (Serranidae: Epinephelinae) no Molhe Oeste da Barra de Rio Grande, Rio Grande do Sul, Brasil. PanamJAS 2:279-287

> Condini MV, Fávaro LF, Varela AS Jr, Garcia AM (2014a) Reproductive biology of the dusky grouper (Epinephelus marginatus) at the southern limit of its distribution in the south-western Atlantic. Mar Freshw Res 65:142-152

Condini MV, Albuquerque CQ, Garcia AM (2014b) Age and growth of dusky grouper (Epinephelus marginatus) (Perciformes: Epinephelidae) in the southwestern Atlantic, with a size comparison of offshore and littoral habitats. Fish Bull 112:311-321

Cornish A, Harmelin-Vivien M (2004) Epinephelus marginatus. In: 2006 IUCN Red List of Threatened Species. www.iucnredlist.org (accessed 5 December 2013)

Craig MT, Sadovy de Mitcheson YJ, Heemstra PC (2011) Groupers of the world: a field and market guide. CRC Press, Boca Raton, FL

> Darnaude AM, Sturrock A, Trueman CN, Mouillot D, Campana SE, Hunter E (2014) Listening in on the past: What can otolith $\delta 180$ values really tell us about the environmental history of fishes? PLoS ONE 9:e108539

> Davoren GK, Woloschiniwsky CSA, Haldenb NM, Wang F (2015) Does otolith chemistry indicate the natal habitat of Newfoundland capelin Mallotus villosus? J Exp Mar Biol Ecol 464:88-95

> Elsdon TS, Gillanders BM (2005) Alternative life-history patterns of estuarine fish: barium in otoliths elucidates freshwater residency. Can J Fish Aquat Sci 62:11431152

Elsdon TS, Wells BK, Campana SE, Gillanders BM and others (2008) Otolith chemistry to describe movements and life-history parameters of fishes: hypotheses, assumptions, limitations and inferences. Oceanogr Mar Biol Annu Rev 46:297-330

> Garcia AM, Vieira JP, Winemiller KO (2003) Effects of 1997-1998 El Niño on the dynamics of the shallow-water fish assemblage of the Patos Lagoon estuary (Brazil). Estuar Coast Shelf Sci 57:489-500

Garcia AM, Vieira JP, Winemiller KO, Grimm AM (2004) Comparison of the 1982-1983 and 1997-1998 El Niño effects on the shallow-water fish assemblage of the Patos Lagoon estuary (Brazil). Estuaries 27:905-914

Gibson-Reinemer DK, Johnson BM, Martinez PJ, Winkelman DL, Koenig AE, Woodhead JD (2009) Elemental signatures in otoliths of hatchery rainbow trout (Oncorhynchus mykiss): distinctiveness and utility for detecting origins and movement. Can J Fish Aquat Sci 66:513-524

Graham RT, Rhodes KL, Castellanos D (2009) Characterization of the goliath grouper Epinephelus itajara fishery of southern Belize for conservation planning. Endang Species Res 7:195-204

Heemstra CP, Randall JE (1993) FAO species catalogue Fisheries Synopsis 16. In: Heemstra CP, Randall JE (eds) Groupers of the word (family Serranidae, subfamily Epinephelinae), an annotated and illustrated catalogue of the grouper, rockcod, hind, coral grouper lyretail species. FAO, Rome, p 186-189

> Kraus RT, Secor DH (2004) Incorporation of strontium into otoliths of an estuarine fish. J Exp Mar Biol Ecol 302: 85-106

Mai AC, Condini MV, Albuquerque CQ, Loebmann D, Saint' Pierre TD, Miekeley N, Vieira JP (2014) High plasticity in habitat use of Lycengraulis grossidens (Clupeiformes, Engraulididae). Estuar Coast Shelf Sci 141:17-25

Marohn ML, Prigge E, Zumholz K, Klügel A, Anders H, Hanel R (2009) Dietary effects on multi-element composition of European eel (Anguilla anguilla) otoliths. Mar Biol 156:927-933

> Moller OO, Casting P, Salomon LC, Lazure P (2001) The influence of local and non-local forcing effects on the subtidal circulation of Patos Lagoon. Estuaries 24: 297-311

Pereyra PR (2015) Assimilação de recursos alimentares e uso de habitats estuarino e límnico pelo bagre guri Genidens genidens (Cuvier, 1829). PhD dissertation, University of Rio Grande, Rio Grande do Sul, Brazil

Phillis CC, Ostrach DJ, Ingram BL, Weber PK (2011) Evaluating otolith $\mathrm{Sr} / \mathrm{Ca}$ as a tool for reconstructing estuarine habitat use. Can J Fish Aquat Sci 68:360-373

Reis-Santos P, Vasconcelos RP, Ruano M, Latkoczy C, Günther D, Costa MJ, Cabral HN (2008) Interspecific variations of otolith chemistry in estuarine fish nurseries. J Fish Biol 72:2595-2614

Reis-Santos P, Tanner SE, Vasconcelos RP, Elsdon TS, Cabral HN, Gillanders BM (2013a) Connectivity between estuarine and coastal fish populations: contributions of estuaries are not consistent over time. Mar Ecol Prog Ser 491:177-186

> Reis-Santos P, Tanner SE, Elsdon TS, Cabral HN, Gillanders BM (2013b) Effects of temperature, salinity and water composition on otolith elemental incorporation of Dicentrarchus labrax. J Exp Mar Biol Ecol 446:245-252

> Reñones O, Polunin NVC, Goni R (2002) Size related dietary shifts of Epinephelus marginatus in a western Mediterranean littoral ecosystem: an isotope and stomach content analysis. J Fish Biol 61:122-137

> Rooker JR, Secor DH, Metrio G, Schloesser R, Block BA, Neilson JD (2008) Natal homing and connectivity in Atlantic bluefin tuna populations. Science 322:742-744

Sadovy de Mitcheson Y, Craig MT, Bertoncini AA, Carpenter KE and others (2013) Fishing groupers towards 
extinction: a global assessment of threats and extinction risks in a billion dollar fishery. Fish Fish 14:119-136

Seyboth E, Condini MV, Albuquerque CQ, Varela AS Jr, Velasco G, Vieira JP, Garcia AM (2011) Age, growth, and reproductive aspects of the dusky grouper Mycteroperca marginata (Actinopterygii, Epinephelidae) in a manmade rocky habitat in southern Brazil. Neotrop Ichthyol 9:849-856

Sluka RD, Chiappone M, Sullivan-Sealey KM (2001) Influence of habitat on grouper abundance in the Florida Keys, USA. J Fish Biol 58:682-700

Editorial responsibility: Eduardo Martins, Vancouver, British Columbia, Canada
Sturrock AM, Trueman CN, Darnaude AM, Hunter E (2012) Can otolith elemental chemistry retrospectively track migrations in fully marine fishes? J Fish Biol 81:766-795

Tanner SE, Reis-Santos P, Vasconcelos RP, Fonseca VF, França S, Cabral HN, Thorrold SR (2013) Does otolith geochemistry record ambient environmental conditions in a temperate tidal estuary? J Exp Mar Biol Ecol 441: $7-15$

Walther BD, Thorrold SR (2006) Water, not food, contributes the majority of strontium and barium deposited in the otoliths of a marine fish. Mar Ecol Prog Ser 311:125-130

Submitted: August 4, 2015; Accepted: December 3, 2015 Proofs received from author(s): January 25, 2016 